\title{
EXTENDING THE ROLE OF THE COMMITTEE IN AN \\ UNINCORPORATED ASSOCIATION - A SEPARATE DUTY OF CARE TO MEMBERS AND VISITORS?
}

\author{
Lisa Glennon, School of Law, The Queen's University of Belfast* \\ INTRODUCTION
}

The potential liability of unincorporated associations to their members arose recently in the case of Kinner $\mathrm{v}$ Trustees of West Belfast Pigeon $C l u b{ }^{1}$ The legal problem that this causes is well established: the fact that a member of an unincorporated association cannot sue the association due to the fact that the latter has no legally recognisable identity independent of its members. The identity of the association is merely the totality of the members and the fact that a member would, in effect, be suing himself precludes such an action. In the present case, however, the plaintiff had a dual role in the West Belfast Homing Pigeon Society as a member and as an employee. ${ }^{2}$ He alleged that he injured his back lifting a keg of beer while carrying out his duties as barman. The defendants ${ }^{3}$ claimed that despite the plaintiff being injured while working in his role as barman the fact of his membership precluded him from suing the club. McCollum LJ ruled, however, that the plaintiff's membership of the club was not an immunity against actions and this was upheld by the Court of Appeal. Reference was made to the earlier case of McKinley $\mathrm{v}$ Montgomery ${ }^{4}$ where a lady member of Eglinton Cricket Club, who was injured on club premises, claimed damages against the club under section 2(1) of the Occupiers' Liability Act (Northern Ireland) 1957 and common law negligence. ${ }^{5}$ Shiel $\mathrm{J}$ held that the fact of her membership precluded her from successfully suing the respondents as the nominated representatives of her fellow members as there was no real distinction between them and, as such, she was owed no duty of care. This was upheld by the Court of Appeal. However, relying on earlier authority, ${ }^{6}$ Hutton LCJ in the course of his judgment accepted that -

"... whilst the mere fact of common membership of a club does not by itself give rise to a duty of care owed to one member by all the other members, none the less because of the special responsibilities undertaken by a member or a group of members, he or they may become liable under the principle of Donoghue v Stevenson to another member, and the duty of

* This is the first of two conjoined articles. The second, 'Questioning the Legal Status of Unincorporated Associations', will appear in the Northern Ireland Legal Quarterly, Spring 2000. I would like to thank David Capper and an anonymous referee for commenting on an earlier draft.

1 [1998] 7 BNIL 91.

2 The plaintiff was employed by the club as a barman.

3 The defendants were identified as those members representing the club as employers other than the plaintiff himself.

4 [1993] NI 93. See Capper, 'Negligence Actions Against Unincorporated Associations' (1993) 44 NILQ 388 for a discussion of this case.

5 The respondents to the action were members of the club sued as the nominated representatives of the club.

6 Jones v Northampton Borough Council [1992] 156 L,G, Rev, 23 
care thereby arising cannot be excluded by the fact that the plaintiff and the defendant or defendants are members of the same club".?

The main question in Kinner v Trustees of West Belfast Pigeon Club ${ }^{8}$ was whether this principle applied in a reverse context: in other words, whether a duty of care can be owed to a member due to the special responsibilities undertaken by him. MacDermott LJ held that the duty of care under Donoghue v Stevenson ${ }^{9}$ may be owed to a club member undertaking special responsibilities as an employee, signifying an extension of the principle outlined by Hutton LCJ in McKinley v Montgomery. ${ }^{10}$ However, this adds little to the debate regarding the rights of ordinary members of an association or club. Indeed, the established principle that there is no distinction between members of a club giving rise to a duty of care owed by certain members to others was supported and the application of this principle to the position of committee members was expressly upheld. ${ }^{11} \mathrm{~A}$ distinction could be made in the present case between the plaintiff and the other club members as he was also employed by the club and it was in this capacity that he was injured. It seems, therefore, that two principles can be extrapolated from the Kinner case. First, there is no immunity for one member of a club against a claim by another member on the basis of their common membership of the club. If the required conditions of duty of care and consequent negligence are satisfied then an action can proceed. Secondly, ordinary employment law principles apply and the duties and responsibilities of an employer are not avoided in this type of case due to the employee's membership of the club or association. The fact of the plaintiff's membership did not preclude the action, but it did not give rise to the duty of care either. The liability of the defendant arose because of the duty which all employers owe to their employees both at common law and under the wide range of statutory provisions.

The diverse outcome of Kinner and McKinley illustrates the anomalous position of club members which justifies Lord Romilly's assertion that "clubs are very peculiar institutions". 12 On the bare facts of these two cases members were injured on club premises, one was owed a duty of care because he was injured in another capacity, the other was not. Several issues arise as a result of this, which will be discussed in this and a subsequent article. ${ }^{13}$ The present article will consider the preliminary question of whether an ordinary member of an unincorporated association should be able to sue the association. If it is accepted that they should have such legal redress the next question concerns the legal basis facilitating this. In this context the role of the committee needs to be assessed to decide whether the principle of a member voluntarily undertaking special responsibilities as an officer of the club justifies the imposition of a duty of care on him. Alternatively, it will be discussed in the subsequent article whether tailor-made legislation giving non-profit associations separate legal personality should be introduced and, if so, on what basis? Finally, and in conjunction with this, is the question of whether an association of this nature could either limit or exclude liability under the Unfair Contract Terms Act 1977.

7 Supra, n 4 at 103. In McKinley it was not asserted that any servant or agent of the members was personally liable in negligence.

8 Supra, $\mathrm{n} 1$.

9 [1932] AC 562.

10 Supra, $\mathrm{n} 4$

11 See Prole v Allen [1950] 1 All ER 476.

12 Hopinkson v Marquis of Exeter (1867) L. R. 5 Eq. 67.

13 L. Glennon, Questioning the Legal Status of Unincorporated Associations, Northern Ireland Legal Quarterly, Spring 2000. 


\section{SHOULD A MEMBER BE ABLE TO SUE THE ASSOCIATION?}

The basis of this article is premised on the assumption that a member of an unincorporated association should be able to obtain redress from the association itself for injury caused while on the association's premises. However, an initial question that has to be asked is whether this is justifiable. If one considers the cases of McKinley and Kinner it becomes apparent that, in the absence of special circumstances ${ }^{14}$, an injured member will have no legal redress if injured on club premises. It will be seen in the next section that the complexity involved in assessing the circumstances in which one member will owe a duty of care to the other club members makes it very difficult to state clearly to whom a duty of care will be owed, either under the Occupiers' Liability Act (Northern Ireland) 1957 or common law negligence. The unpredictability caused by this justifies legal intervention. However, an argument against a member being able to sue an association is that once a member pays his subscription all he is entitled to is use of the premises and facilities. On top of this is the economic argument that the possibility of legal action and awards of compensation is a financial burden some associations may not be able to withstand. The possibility of legal actions means that associations would be advised to obtain insurance to meet any costs. It is likely, however, that such a burden would be met by increased membership fees, so what members may possibly gain on one hand is lost on the other. Inextricably linked to these issues is the fact that unincorporated associations encompass a diversity of groups, each with varying degrees of transience ${ }^{15}$. This makes finding a solution to the problem an even more difficult task.

The anomalous position of club members, however, warrants a thorough examination into the ways in which their rights could be strengthened. The irony that visitors and trespassers ${ }^{16}$ are better protected when they suffer injury on club premises begs the question why members should not enjoy comparable rights. The argument that the members' entitlement on joining a club or association is limited to the use of the club premises and facilities is a rather restrictive view of their reasonable expectations. Indeed, one could argue that it is not necessarily a well-established policy argument that precludes members from suing, but the legal technicality that an unincorporated association lacks a legal identity independent of its members. It does not seem unreasonable that someone should bear the

14 In Kinner the special circumstances were that that plaintiff member was injured in his capacity as a barman of the club.

15 The implications of the diversity of unincorporated associations was outlined by Tritschler J. in Tunney v Orchard [1955] 3 D,L,R, 15 at 50: "The present state of the law may be attributed to a failure to recognise differences in fact among voluntary, unincorporated associations; a failure to see that some are entities in fact and some are not. There is a real distinction in fact between, on the one hand, a loosely associated religious order of 1800, whose members are scattered throughout the world ..., or a propertyless, vaguely organized association to advance the interests of merchants in a section of Toronto ... In the former there may be an entity in fact apart from its membership, with assets which can and ought to be applied to the satisfaction of the obligations incurred."

16 The position of an occupier in relation to trespassers is found in the Occupiers' Liability (Northern Ireland) Order 1987. This provides that an occupier owes a duty of care to any person in respect of a risk against which he may reasonably be expected to offer that person some protection. The standard required is to take such care as is reasonable in all the circumstances. 


\section{Northern Ireland Legal Quarterly [Vol. 50, No. 4]}

responsibility of ensuring that club premises are safe and the technical argument precluding the unincorporated association being sued as a body does not justify the dichotomous legal treatment between the differing categories of plaintiff.

If one accepts the principle that members of unincorporated associations should have legal redress for injury one must decide against whom. The purpose of this article is to consider the possibility of extending the liability of the committee and other officers of the club to facilitate the claims of a member injured on club premises.

\section{SUING THE COMMITTEE AS A SEPARATE BODY}

The possible extension of a committee's liability raises the question of the role of the committee. It could be argued that the committee is a separate elected body with the implied responsibility of ensuring the safety of club premises. On this basis the holding of office is the distinguishing factor between a committeeman and the other ordinary members of the club. Of course it is open to the committee, as a body, to delegate certain responsibilities to individual officers, but in the absence of this the committee would be wholly responsible. However, this is not the present position. At present the committee is viewed as an agent of the club members. On this analysis it seems that it is the members collectively, acting through the committee, who are responsible for the management of the club -

“... the management committee of the club were doing no more than acting as agents for all the members. They were elected by the members and they were exercising the powers of all the members as agents for those members. They were not a body with individual members nor had they any separate entity for the purpose of contracting with outsiders who came with members of the club". ${ }^{17}$

In the case of personal injury to members and non-members the Occupiers' Liability Act (Northern Ireland) 1957 imposes on occupiers a common duty of care to all visitors. On the basis that the management of the club is the responsibility of the members collectively, albeit acting through the committee, the 'occupier' for the purposes of the legislation is the collective body of members. ${ }^{18}$

This is not to say, however, that the committee, as a body, or individual officers will never be held personally responsible for the safety of the club's premises. The de facto immunity of the committee and club officers can be displaced by the individual officer undertaking special

17 Shore v Ministry of Works [1950] 2 All ER 228 at 231 per Tucker LJ. This is emphasised by Josling who says that " ... the contract of membership is a contract among the members themselves and the committee of the club is not a principal party to it. The committee is the agent of the members of the club as a whole for purposes to be ascertained from the rules ...". Josling, Law of Clubs $\left(6^{\text {th }} \mathrm{ed}, 1987\right)$ at page 90.

18 Warburton states that "A member injured as a result of the state of the associations' premises cannot sue the other members because he is as much an occupier as they are". Warburton, Unincorporated Associations $\left(2^{\text {nd }}\right.$ ed, 1992) at page 74. It should be noted that the possibility of a member injured on club premises suing the management committee in contract has been thwarted by the decision of the Court of Appeal in Shore v Ministry of Works [1950] 2 All ER 228 which held that the contract of membership does not contain an implied term that the premises were and would be safe. 
responsibilities as in Prole v Allen ${ }^{19}$ where the club steward ${ }^{20}$ was held responsible for ensuring the safety of the club premises for the members. Certain alterations had been carried out on some steps and the plaintiff member, unaware of this, fell down them and was injured. Prior to the accident the steward had switched off a light, which had been placed near the steps. It was held that the steward was liable as he had been given express responsibility for the condition of the club's premises by all the members acting through the committee. ${ }^{21}$ This placed him under a duty of care, which he had breached. ${ }^{22}$ Although the committee was responsible for the management of the club it was held that the committee members did not owe a duty of care to the plaintiff.

This can also be seen in the case of Robertson $\mathrm{v}$ Ridley ${ }^{23}$ where the rules of the club provided that the club was to be run by the committee but that the secretary and the chairman were responsible in law for the conduct of the club. The question was whether the plaintiff member, injured when his motorcycle hit a pothole in the drive to the club, was owed a duty of care. The Court of Appeal held that the rules did not impose on those officers a responsibility for the condition of the club premises and construed them as merely indicating who was responsible for the club's liability. May LJ, who had reservations about the liability of the steward in Prole v Allen, held that the words "responsible in law for the conduct of the club" meant that the secretary and chairman were responsible for such duties the law already imposed on the club. Nourse LJ interpreted the words as meaning that the named officers were responsible in law for the conduct of the members as a group "observing the requirements of statute and regulation in the running of the club and perhaps as regards liability towards third parties as well' ${ }^{24}$ On this interpretation it seems that it was anticipated that the two officers would be sued as representative members in the case of any liability against the club. If one accepts that the rules did not render the officers personally liable to the members, it seems logical to conclude that the wording would also have been insufficient to impose personal liability on the officers vis-à-vis visitors. On this analysis of the rules, a non-member would sue the named officers but responsibility would be on the members collectively.

The question of whether the rules would have imposed on the named officers a separate duty of care to visitors in Robertson $\mathrm{v}$ Ridley ${ }^{25}$ is an interesting one. Whether or not the committee or individual officers personally owe a duty of care is to be decided on the rules of the

19 Supra, n 11.

20 Who was also a member and committeeman of the club.

21 The steward admitted in his evidence that "It was my duty to open the club and to close it, to remain on the premises until everybody had left, and to put the lights on and to turn the lights off when and where necessary. It was my duty ... to see that the premises were in as good order as they should be, and in a fit condition for use by members of the club ...". Supra, n 11 at 478 .

22 Pritchard $\mathrm{J}$ outlined the rationale for distinguishing between the role of the committee and the role of the steward in relation to the other members: "He was appointed by all the members, operating through the committee, and, in my judgment, he thereupon became the agent of each member to do reasonably carefully all those things which he was appointed to do, and in that way he came to owe a duty to each of the members to take reasonable care to carry out his duties without negligence". Supra, n 11 at 477.

23 [1989] 2 All ER 474.

24 Ibid, at 478.

25 Supra, n 23. 
association and this assessment should not really differ whether the plaintiff is a member or a visitor. However, in Prole v Allen ${ }^{26}$ on the issue of the liability of the committee Pritchard $\mathbf{J}$ opined that the decision of Brown v Lewis ${ }^{27}$ was of no assistance as in that case the plaintiff was a stranger whereas the present case concerned an action by a member ${ }^{28}$. It could be argued, therefore, that the identity of the plaintiff affects the reasoning of the court.

The cases discussed illustrate that membership of a committee does not, by itself, give rise to a duty of care towards the other members. However, this does not mean that committee members have an absolute immunity against actions by fellow members. ${ }^{29}$ The question that has to be considered, therefore, is the requirements necessary to give rise to this duty of care. If club rules delegate the general responsibility for the management of the club and its premises to the committee should this be sufficient to impose on that body a separate duty of care to both members and visitors?

\section{A SEPARATE DUTY OF CARE TO MEMBERS AND VISITORS?}

In the case of Grice v Stourport Tennis, Hockey and Squash Club ${ }^{30}$ the plaintiff member injured his back as he was entering the clubhouse. He alleged negligence on the ground that the step leading into the clubhouse was sloping and that it had a smooth stainless steel surface. The plaintiff's solicitor issued proceedings against the club, citing the name of the club, which was an unincorporated association, instead of the representative members. The plaintiff issued a summons to amend the statement of claim adding two individuals as representative members, the trustees, the chairman of the ground and premises committee and the steward on behalf of themselves and all the other members. The summons was struck out on the ground that there was no cause of action. This was upheld by Bracewell $\mathbf{J}$ who opined that the plaintiff could not sue the representative members as he would, in effect, be suing himself. The plaintiff appealed on the ground that he could make amendments to his statement of claim. The appeal was allowed by the Court of Appeal holding that the statement

Supra, n 11.

7 (1896) 12 TLR 455.

28 Another reason cited by Pritchard J was that in Brown $\mathrm{v}$ Lewis no distinction was made between a committee member and an ordinary member of the club. However, on the facts the committee were held personally liable for employing an incompetent person to repair a stand which collapsed and injured a member of the paying public. Indeed, the action was originally brought against the members of the committee as representing the whole club, but Cave $\mathbf{J}$ held that the committee were the persons responsible. His Lordship said that the committee " ... had the power and duty of providing a stand for the accommodation of visitors to the football ground. They employed an incompetent man to repair the stand, and an accident resulted. The persons to blame were the committee".

29 In Jones v Northampton Borough Council Gibson LJ commented that “... there is nothing in the case of Prole or Robertson v Ridley upon which can be founded a form of immunity available in law to one member of a club against a claim by another member of the club, being an immunity based upon their joint membership if the claimant can demonstrate that, according to the ordinary principles of law, the defendant member of the club was under a duty of care in respect of the circumstances which caused the claimant's injury and that the defendant was guilty of negligence". Supra, n 6 at 29.

30 Unreported, Court of Appeal 28 February 1997. 
of claim could be amended to add representative members of the club to be sued on their own behalf and on behalf of all the other members. ${ }^{31}$ In addition, the trustees, the chairman of the ground and premises committee and the steward could also be added as the law did not prevent a member of a club from suing his fellow members who adopted a responsibility which gave rise to a duty of care.

It is relevant that the court allowed the plaintiff to add the trustees, the chairman of the ground and premises committee and the steward. ${ }^{32}$ An analysis of the rules provided evidence that certain officers of the club may have accepted responsibility for the safety of the club's premises. The rules of the club stated that the management of the club was vested in the executive committee. Furthermore, it was stated in rule 9 that the ground and premises committee were responsible for the management of all the club's grounds, buildings and equipment. The divergence of approach between Bracewell $\mathrm{J}$ and the Court of Appeal is indicative of the difficulty in maintaining consistency when rules are being interpreted. Bracewell J opined that rule 9 did not give rise to any obligation, simply referring to housekeeping matters as opposed to any responsibility for the safe condition of the premises. Beldam LJ, in the Court of Appeal, thought that this interpretation was too restrictive. Similarly, Otton LJ said that it was at least arguable that rule 9 showed that the members anticipated that the ground and premises committee were to be responsible for the management of club grounds, buildings and equipment. More significantly, it was held to be at least arguable that the responsibility delegated to the committee was a duty, not merely for the benefit of visitors to the club, but also for the benefit of the members. This is an important assertion which correlates with the point made earlier that there will often be a body of members, probably the committee or subcommittee, who will bear the responsibility of ensuring that the premises are reasonably safe for visitors. This begs the question of why a comparable duty should not be owed, by the same body of people, to club members.

In the course of his judgment Beldam LJ noted that the club's insurance was on a member to member basis. This meant that the insurance cover was not exclusively for guests or visitors on the premises, but covered the liability of one member towards another. While this would cover the situation where the negligence of one member caused injury to another, it also -

“. . . would seem adequate to cover a situation in which one member or one or more members were entrusted by the other members as part of a committee to see that the property ... was properly managed and maintained ..." 33

This position complemented rule 9 of the club regarding the acceptance of responsibility by the committee, thus adding credence to the argument that the committee's responsibility was not just for the benefit of visitors to the club but for the benefit of members. Such an acceptance of responsibility makes it reasonable for members to expect the committee to carry out their duties with the requisite care and skill. The fact remains, however, that a duty of care to members will not be implied and that the only authority acceded to a club's committee is that given expressly or by necessary

31 Applying Murray v Hibernian Dance Club [1997] P,I,Q,R, P46.

32 Reference was made to Jones v Northampton Borough Council, supra, n 6.

33 Grice v Stourport Tennis, Hockey and Squash Club, 28 February 1997. 


\section{Northern Ireland Legal Quarterly [Vol. 50, No. 4]}

implication in the rules. ${ }^{34}$ This further adds to the disparity between cases as the rules of a club will vary from case to case. The rules may narrowly define the remit of the committee's responsibilities and the interpretation of those rules is, at the end of the day, a matter for the court. ${ }^{35}$

\section{Members' reasonable expectations}

Inextricably linked with this is the contractual question regarding the reasonable expectations of club members. It could be argued that extending the liability of committeemen and officers gives unreasonable expression to the members' expectations, especially in the case of small associations. That club members are not automatically entitled to expect club premises to be safe was beyond doubt in the case of Shore v Ministry of Works ${ }^{36}$ where it was held that the contract of membership does not include an implied warranty that club premises were and would be safe. Jenkins LJ said that the members' rights include -

". . . the right from time to time to use the club premises, with all their defects or imperfections. There was nothing in the nature of a special contract between the plaintiff and the committee of management ..." 37 .

However, once a member subscribes to a club or association they are admitted to the club's membership on the terms of its rules. The expectations of the club's members will derive from the rules and if the management of the club is delegated to the committee it could be argued that the ordinary members are entitled to expect the requisite degree of care and skill from the elected committee who have accepted office on the terms of the rules. It is submitted that this general managerial responsibility encompasses, by implication, a responsibility for the safe condition of the club's premises. This argument is premised on the submission that a separate duty of care is owed not just to visitors but also to the ordinary members.

Facilitating a member's action against the committee may be in line with the test of 'occupation' under the Occupiers' Liability Act (Northern Ireland) 1957 . It seems that occupation correlates with control over the premises, as noted by Lord Denning in Wheat $\mathrm{v}$ E. Lacon \& Co. Limited ${ }^{38}$ that the word occupier -

“. . . was simply a convenient word to denote a person who had a sufficient degree of control over premises to put him under a duty of care towards those who came lawfully on to those premises". ${ }^{39}$

34 Supra, n 18 at page 87.

35 Lee v The Showman's Guild of Great Britain [1952] 2 QB 329 at 344 Denning LJ said that "The rules are a contract between the members. The committee cannot extend their jurisdiction by giving a wrong interpretation to the contract, no matter how honest they may be. They have only such jurisdiction as the contract on its true interpretation confers on them, not what they think it confers. The scope of their jurisdiction is a matter for the courts, and not for the parties, let alone for one of them".

36 [1950] 2 All ER 228.

37 Ibid, at 232.

38 [1966] AC 552.

39 Ibid, at 577. Lord Denning quoted Salmond on Torts (14 th ed, 1965), p 372: “. . . an 'occupier' is he who has the immediate supervision and control and the power of permitting or prohibiting the entry of other persons". Lord Denning thought that this was too narrow and said that a degree of control over the state 
The inclusion of the control element of the occupation test serves as a ground upon which to develop the liability of the committee of the unincorporated association and to hold that the managerial responsibility of the committee makes them 'occupiers' for the purposes of the Occupiers' Liability Act (Northern Ireland) 1957.

\section{The Bradley Principle}

This pragmatic approach to the position of committee members is broadly in line with the words of Scott LJ in Bradley Egg Farm v Clifford ${ }^{40}$ where the key question was the identity of the person with whom a third party made a contract in an unincorporated association. Scott LJ said that -

"The law . . . has to choose from the various persons associated together under the umbrella of the society's name, those most concerned in the function of making contracts, those of the associated persons who were most directly concerned, and to discard those who were, for any reason, least directly concerned". ${ }^{41}$

Although this principle was stated in a contractual context it is a useful approach to adopt generally when considering the position of the committee in an unincorporated association. Indeed, in the Australian case of Smith v Yarnold ${ }^{42}$ the reasoning utilised in Bradley was considered to be equally applicable to both contract and tort issues. ${ }^{43}$ In this case the plaintiff, who was a spectator at a greyhound meeting at Taree Greyhound Racing Club, was injured when the grandstand collapsed. He sued the members of the committee of the club under an alleged breach of warranty as to the safety of the grandstand and for negligence. The New South Wales Court of Appeal, applying the reasoning used in Bradley, held the committee members liable. On this point Herron CJ concluded that -

"The liability of the committee men of the Greyhound Racing Club does not depend wholly upon a logical approach to the law of contract or of tort, none the less it is the only method by which justice can be done towards the plaintiff who paid his admission fee and was entitled to expect the security which the invitation involved". ${ }^{44}$

This case was considered by the Supreme Court of Western Australia in City of Gosnells v Roberts. ${ }^{45}$ The plaintiffs were injured when a horse strayed from land, owned by the City of Gosnells Council and occupied by an unincorporated polocrosse club, and collided with their motorcycle on a public road. The plaintiffs sued the owner of the horse, the City Council and the members of the committee at the time of the accident. ${ }^{46}$ The trial judge found all the defendants liable to the plaintiffs. The Supreme Court

of the premises will suffice for occupation. See also Francis v Cockerell (1870) L,R, 5 Q,B, 184.

40 [1943] 2 All ER 378.

41 Ibid, at 386.

42 (1969) 2 NSWR 410.

43 See Fletcher, The Law Relating to Non-Profit Associations in Australia and New Zealand (1986), p 136.

44 Supra, n 42 at 415.

45 [1994] A,T,R, 61-841.

46 They also sued the current members of the committee for the limited purpose of having access to the assets of the club. 


\section{Northern Ireland Legal Quarterly [Vol. 50, No. 4]}

of Western Australia upheld the appeal of the members of the committee ${ }^{47}$ on the basis that the accident did not take place during a polocrosse match. The horse, which caused the accident, was being agisted on the polo grounds during the off-season and as this was outside the objects on the unincorporated body neither the members collectively nor the committee were responsible. Keeler rightly observes, however, that the court in this case was diverted from the key issue of who had the power of control over the land from which the pony strayed ${ }^{48}$. The fact that the activity causing the accident was outside the objects of the club should not have been the determining factor when answering this question ${ }^{49}$. It is notable, however, that Rowland $\mathbf{J}$ said that in accordance with the principle enunciated by Herron CJ in Smith v Yarnold committee members could, in certain circumstances, be primarily responsible in tort. ${ }^{50}$ It is also interesting that the trial judge in this case held the committee liable saying that the law had taken a pragmatic approach to this question. Keeler suggests that it is likely that this is the correct choice -

“. . . it seems likely that running its affairs between them, including ensuring that the playing fields were available and suitable for . . . use, seems to have been left to the committee ... [ [which] is the body most likely to be responsible for seeing that [the fields] are cut, cleared, marked and looked after and these responsibilities would extend to their security as well as their general condition". ${ }^{51}$

Such an interpretation of the role of the committee, although discussed in relation to visitors injured on club premises, is similarly applicable when a member is injured on club premises. This is in line with the reasoning of Grice v Stourport Tennis, Hockey and Squash Club ${ }^{52}$ that if the committee undertook and accepted managerial responsibility it is not unreasonable that a duty of care is owed to members as well as visitors. Indeed, in Grice Otton LJ cited and approved the words of Gibson LJ in Jones v Northampton Borough Council ${ }^{53}-$

"It seems to me that it is open to the court to find that a duty of care existed where a club officer or member of a committee takes upon himself some task which he is to perform for other members of the club in the course of which he acquires actual knowledge of circumstances which he knows give rise to risk of injury to club members acting as he knows they will or may be expected to act if they are not told of the cause of danger". ${ }^{4}$

It is submitted that the appointment of committee members, a delegation of general managerial responsibility to them and their acceptance of this responsibility satisfy this requirement. This would give sufficient control

47 The liability of the owner of the horse and the City Council was affirmed.

48 Keeler, 'City of Gosnells v Roberts: Coping with Unincorporated Associations', (1995) Torts Law Journal, Lexis 9.

49 Keeler states that “ ... the fact that agisting ponies during the off-season was outside the objects of the club is irrelevant to the identity of the persons having sufficient control over the land to be held responsible for the exercise of reasonable care to prevent harm to highway users". Ibid.

50 Supra, n 45 at 61-847. Pidgeon J. similarly considered that the reasoning of Herron CJ in Smith v Yarnold may be applicable to render the committee liable in negligence if a highway user was injured during a polocrosse game.

51 Supra, n 48.

52 Supra, n 30

53 Supra, n 6.

$54 \mathrm{Ibid}$, at 29. 
to the committee over club premises to be responsible for their safety and condition for the benefit of both members and visitors. It seems, therefore, that when determining the identity of the occupier of club premises Bradley Egg Farm v Clifford ${ }^{55}$ offers a sensible approach, that is looking at the various persons within the association to determine who is most concerned with ensuring that the club premises are in a safe condition. Generally, this is not the responsibility of the members who will have elected the committee to fulfil, inter alia, this task. ${ }^{56}$

\section{CONCLUSION}

This interpretation of the role of the committee would enable a member to obtain redress when injured on association premises, thus overcoming the present procedural difficulties. When questioning whether this is too onerous a duty in the context of negligence actions it should be remembered that the common duty of care is to take such care as is reasonable in the circumstances. For the purposes of the legislation the 'occupier' does not have to guard against improbable, even if foreseeable, events. ${ }^{57}$ However, various arguments could be advanced against this development. One argument is that rendering the committee liable is too harsh a burden on mere volunteers, that the committee as a body do not enjoy the profits of the club, if there are any, so why should they carry the liabilities? Laski puts forth a similar argument about the case of Brown v Lewis $^{58}$

“. . . sanity would appear to require that just as the club would have enjoyed the profits, so, on the collapse of the stand, it is right that it should suffer the penalties". 59

However, a similar question can be asked from the point of view of the members. Why should the members collectively bear the responsibility of being 'occupiers' under the Occupiers' Liability Act (Northern Ireland) 1957 when they are not the body with control over the condition of the club's premises? When looking at this question it is interesting to consider the identity of the 'occupier' in other contexts. For the purposes of the General Rate Act 1967 the 'occupier' of land is liable to pay rates. The Court of Appeal in Verrall $\mathrm{v}$ Hackney London Borough Council ${ }^{60}$ held that in the context of an unincorporated association, being a member

55 Supra, $\mathrm{n} 40$.

56 In Smith v Yarnold (1969) 2 NSWR 410 Herron CJ stated in the course of his judgment that as regards the liability of the committee the summations of the trial judge, who stated that the basis of the plaintiff's claim was the fact that the committee members were chosen to manage the affairs of the club and they accepted this situation, had been correct.

57 Jones, Textbook on Torts, $\left(6^{\text {th }}\right.$ ed, 1998). See also Bolton v Stone [1951] AC 850.

58 Supra, $\mathrm{n} 27$.

59 Laski, 'The Personality of Associations', (1915-16) 29 Harv. L. Rev. 404 at 420. A similar argument can be advanced against imposing liability on trustees solely on the basis that they are the legal owners of the club's property. There is at present no basis on which to hold trustees liable to either members or nonmembers and it seems that a stronger case could be made for rendering the committee liable than the trustees on the grounds that the former generally will be elected by the members to carry out the management of the club.

60 [1983] 1 Q,B, 445 
is insufficient by itself to render a person an occupier for these purposes. May LJ stated, per curiam, that -

"Most unincorporated associations, such as clubs or charities, have trustees, or a committee, legal persons with funds available to pay the rates which it is recognised will have to be paid. It is these persons who, as a matter of law, usually occupy the relevant premises which are used for the purpose of their club or charity and are liable as such occupiers for the general rates". 61

However, one practical difficulty, which cannot easily be overlooked, is that usually the committee of a club will be unpaid volunteers and to extend their liability may have the effect of reducing the number of volunteers willing to undertake this role. ${ }^{62}$ Furthermore, the rules of the club will continue to be the starting point for determining the liability of committee members and as the rules will vary from club to club inconsistencies are inevitable. An economic argument is that it may be advisable to purchase insurance to cover the committee and other officers of the club against potential liability. This cost would probably be met by the members as subscriptions would increase to meet this extra financial burden. These points may weigh in favour of the second option, statutory incorporation of clubs and associations. This would answer Laski's claim that -

"... it would appear to the man in the street more equitable to make the club pay for that which it enjoys the benefit. . ." ${ }^{63}$

A second article, therefore, will consider the mechanics of conferring a separate legal identity on clubs and associations. It will be argued that such statutory incorporation would not merely solve the present issue of

${ }^{61}$ Ibid, at 462. See Fletcher, The Law Relating to Non-Profit Associations in Australia and New Zealand (1986), p 137.

${ }^{62}$ One option open to office holders of this kind, however, is to attempt to limit or exclude liability by use of a public notice or by inserting an exclusion clause into the club's rules. The enforceability of such a term depends on the application of the Unfair Contract Terms Act 1977, section 2(1) of which prohibits businesses from excluding liability for death or personal injury and from excluding liability for other damage beyond a point which is reasonable. Non-business entities, however, are not bound by the restraints of the 1977 Act. The question, therefore, depends on the interpretation of 'business'. There is little guidance as to what constitutes a 'business' under the Unfair Contract Terms Act, section 14 of which defines a business as including "a profession and the activities of any Government department or local or public authority". Section 1(3) of the Unfair Contract Terms Act 1977, amended by article 4 of the Occupiers' Liability (Northern Ireland) Order 1987, excludes from 'business liability' a duty regarding the dangerous state of premises towards a person gaining access for recreational or educational purposes, unless the granting of access falls within the business purposes of the occupier. When dealing with the liability of individual committee members, it is likely that their activities within the club would not be regarded as business for the purposes of the Unfair Contract Terms Act 1977, thus enabling them to exclude liability unfettered by the restraints of this Act. While this would defeat the claims of a member injured on club premises, all members would have notice of the clause and, as such, their reasonable expectations would not be infringed.

63 Supra, n 59 at 420. 
the rights of members injured on club premises, but would regulate the internal and external affairs of such associations and reduce considerably the complexity of the current law. 